\title{
Anti-inflammatory activity of ethanolic leaf extract of dalbergia sissoo in vitro and in vivo
}

\begin{abstract}
The anti-inflammatory activity of Dalbergia sissoo ethanolic leaf extract (DSELE) was evaluated from the tests of HRBC (human red blood cell) membrane stabilization in vitro and cotton pellet granuloma test in mice. Inhibition of protein denaturation by DSELE was studied to assess anti-arthritic activity. Extract of D. sissoo in different solvents were evaluated for presence of phytoconstituents in the plant. From the results DSELE showed appreciable HRBC membrane stabilization activity. DSELE at 100 , $200,400,800$ and $1000 \mu \mathrm{g} / \mathrm{ml}$ concentration inhibited protein denaturation $47.62 \pm 2.25$, $55.15 \pm 2.04,56.41 \pm 0.51,77.66 \pm 2.88$ and $78.39 \pm 3.39$ per cent, respectively. In cotton pellet granuloma test in mice DSELE showed dose dependant and significant $(\mathrm{P}<0.01)$ anti-inflammatory activity in all DSELE treated group as compare to controls. In phytochemical analysis D. sissoo extracts revealed the presence of anthroquinone, amino acids, protein, saponin, sterols, tannin, glycosides, flavonoids and phenols.
\end{abstract}

Volume 2 Issue 3- 2017

\author{
Yogita Amrutkar, Hajare SW, Ingawale MV, \\ Bhojane NM, Madhuri Hedau, Ingole RS \\ Department of Pharmacology \& Toxicology, Post Graduate \\ Institute of Veterinary \& Animal Science, India
}

Correspondence: Hajare SW, Assistant Professor, Department of Pharmacology \& Toxicology, Post Graduate Institute of Veterinary \& Animal Science, Akola-444I04, India, Email sunilwhajare@rediffmail.com

Received: October 16, 2016 | Published: May 02, 2017

Keywords: anti-inflammatory, hrbc, cotton pellet granuloma, dalbergia sissoo

\section{Introduction}

Dalbergia sissoo Roxb (Indian rosewood) is an important tree species belonging to the family papilionaceae. It is a medium to large-sized, gregarious deciduous tree, attaining a height up to 30 $\mathrm{m}$ and a girth up to $2.5 \mathrm{~m}$ in a favorable climate (sub-tropical and tropical zones). According to Champion et al. ${ }^{1}$ the Shisham tree is a characteristic species of Khair-sissoo (Acacia catechu-Dalbergia sissoo) primary serial type forest of Asian subcontinent. Dalbergia sissoo is native to the plains occurs naturally at elevation of about $900 \mathrm{~m}$ but sometime occuring up to $1500 \mathrm{~m}$ from the Kabul River in Afghanistan through northern Pakistan, northern India, Nepal, Bhutan and into Assam. Human cultivation has greatly expanded its distribution to Southeast Asia, Africa, the Middle East, the Caribbean, tropical America, and Arizona in the United States. Shisham is a very hardy species and produces valuable timber and can be propagated both by seeds and vegetative parts. ${ }^{2}$

Dalbergia sissoo is broadly used in folk medicine for several diseases. ${ }^{3,4}$ Several biologically active compounds such as flavones, isoflavones, quinines and coumarins have been isolated from Dalbergia sissoo. It also contains tectoridin, caviunin-7-O-glucoside, iso-caviunin, tectorigenin, dalbergin, bio-chanin-A, and 7-hydroxy4-methylcoumarin. The heartwood gave 3,5-dihydroxy-trans-stibene biochanin A, dalbergichromene, dalbergenone and iso-dalbergin. ${ }^{5}$ From the earlier studies scanty literature is available to authenticate anti-inflammatory activity from hydroethanolic extract of Dalbergia sissoo. We report herein, the anti-inflammatory activity of its hydroethanolic extract.

\section{Materials and methods}

\section{Collection and processing of plant material}

The mature green leaves of Dalbergia sissoo (Roxb.) were collected in January-February from the campus of Post Graduate Institute of Veterinary and Animal Science (PGIVAS), Akola and identified from expert Botanist. The shade dried leaves were pulverized to get fine powder. Freshly prepared powder $(100 \mathrm{~g})$ was immersed in $500 \mathrm{ml}$ of $60 \%$ ethanol and kept in orbital shaker at $150 \mathrm{rpm}$ for $48 \mathrm{hrs}$. The resultant solvent filtered through Whatman No.1 filter paper. The filtrate obtained was concentrated to semisolid mass at $45^{\circ} \mathrm{C}$ in hot air oven. The extract thus obtained is termed as D. sissoo ethanolic leaf extracts (DSELE) and was used for further studies.

\section{Animals}

Swiss mice of either sex were procured from the Animal House unit of Department of Veterinary Pharmacology and Toxicology, PGIVAS, Akola. The animals were maintained under standard laboratory conditions and had standard pellet diet with free access to clean drinking water.

\section{Acute toxicity study}

Acute toxicity was performed according to the OECD-423 guide lines. ${ }^{6}$ Eighteen Swiss albino female mice $(20-25 \mathrm{~g})$ were equally divided into three groups and were given DSELE 500, 1000 and $2000 \mathrm{mg} / \mathrm{kg}$, p.o. The animals were observed for $24 \mathrm{~h}$ to record toxic effects and mortality and were further observed for 14 days to record any mortality. Based on acute toxicity studies two safe dose levels of DSELE were selected for in vivo studies.

\section{Hypotonic solution induced HRBC membrane stabili- zing activity}

Membrane stabilization of human red blood cell (HRBC) by DSELE was studied as per the method of Sadique et al. ${ }^{7}$ The blood was collected from healthy human volunteer not taken any NSAIDS for 2 weeks prior to the experiment and collected in heparinized vacutainer. The blood was washed three times with $0.9 \%$ saline and centrifuged simultaneously for 10 minutes at $3000 \mathrm{rpm}$. The packed cells were washed with $0.9 \%$ saline and a $10 \% \mathrm{v} / \mathrm{v}$ suspension was made using phosphate buffer $(154 \mathrm{mM} \mathrm{NaCL}$ in $10 \mathrm{mM}$ Sodium Phosphate Buffer at $\mathrm{pH}$ 7.4) as stock erythrocyte or RBC suspension. Various concentration( $100,200,400,800$ and $1000 \mu \mathrm{g} / \mathrm{ml})$ of DSELE was prepared using distilled water and to each concentration $1 \mathrm{ml}$ of phosphate buffer, $2 \mathrm{ml}$ hyposaline and $0.5 \mathrm{ml}$ of HRBC suspension 
were added. Test solution was incubated at $37^{\circ} \mathrm{C}$ for $30 \mathrm{~min}$ and centrifuged at 3,000 rpm for $10 \mathrm{~min}$ and the hemoglobin content of the supernatant solution was estimated spectrophotometrically at $560 \mathrm{~nm}$. Dexamethasone was used as reference drug and a control was prepared using $1 \mathrm{ml}$ Phosphate buffer, $2 \mathrm{ml}$ distilled water and $0.5 \mathrm{ml}$ HRBC suspension.

\section{Inhibition of protein denaturation}

Inhibition of protein denaturation by DSELE was evaluated invitro with bovine serum albumin. ${ }^{8,9}$ The reaction mixture $(0.5 \mathrm{ml})$ consisted of $0.45 \mathrm{ml}$ bovine serum albumin $(5 \% \mathrm{w} / \mathrm{v}$ aqueous solution) and $0.05 \mathrm{ml}$ of DSELE $(100,200,400,800$ and $1000 \mu \mathrm{g} / \mathrm{ml})$ or Dexamethasone $(100,200,400,800$ and $1000 \mu \mathrm{g} / \mathrm{ml})$ in distilled water. All the above solutions were adjusted to $\mathrm{pH} 6.3$ using $1 \mathrm{~N} \mathrm{HCl}$. The samples were incubated at $37^{\circ} \mathrm{C}$ for $20 \mathrm{~min}$ and the temperature was increased to keep the samples at $57^{\circ} \mathrm{C}$ for 3 minutes. After cooling the samples, $2.5 \mathrm{ml}$ phosphate buffer saline $(\mathrm{pH} 6.3)$ was added to each tube. Absorbance was measured spectrophotometrically at 416 $\mathrm{nm}$ and the per cent inhibition of protein denaturation was calculated.

\section{Cotton pellet granuloma in mice}

Mice were grouped in to four groups of six animals each. The pellets weighing exactly $10 \pm 1 \mathrm{mg}$ each were prepared from $5 \mathrm{~mm}$ section of cotton rolls. The cotton pellets were sterilized in an autoclave for $30 \mathrm{~min}$. Autoclaved cotton pellets weighing $10 \pm 1 \mathrm{mg}$ was implanted S.C. along the axillae of mice under light ether anesthesia as per the method of Winter \& Porter. ${ }^{10}$ DSELE $(200$ and $400 \mathrm{mg} / \mathrm{kg}$ ) suspended in distilled water and dexamethasone $(1 \mathrm{mg} / \mathrm{kg})$ and control group

Table I Effect of DSELE on inhibition of HRBC membrane stabilization (normal saline) were administered orally consecutively from the day of cotton pellet insertion up to 7 days. After the insertion of the pellets, the skin was sutured. The mice were sacrificed on 8th day and pellets covered by the granulation tissue were dissected out and dried in hot air oven at $60^{\circ} \mathrm{C}$ till the constant weight was achieved.

\section{Statistical analysis}

The data of present research work was analysed by one way ANOVA followed by student $t$-test for comparison between test and control using standard statistical method. The t-value at $* * \mathrm{p}<0.01$ were considered for analysis of significance. ${ }^{11}$

\section{Results and discussion}

\section{HRBC membrane stabilization activity}

Five different concentrations viz.100, 200,400,800 and 1000 $\mu \mathrm{g} /$ $\mathrm{ml}$ of both DSELE and dexamethasone were used in this study. The results of HRBC membrane stabilization activity of DSELE is tabulated in Table 1. The DSELE showed dose dependant HRBC membrane stabilization activity with consistent rise in per cent stabilization of HRBC membrane. Mean per cent stabilization of HRBC membrane by DSELE at $100,200,400,800$ and $1000 \mu \mathrm{g} / \mathrm{ml}$ was found to be $65.44 \pm 6.05,66.51 \pm 6.81,68.65 \pm 5.11,70.8 \pm 5.32$ and $73.09 \pm 5.63$, respectively, while mean per cent stabilization of HRBC membrane by dexamethasone at $100,200,400,800$ and $1000 \mu \mathrm{g} / \mathrm{ml}$ was found to be $58.26 \pm 6.03,65.14 \pm 1.49,68.60 \pm 2.43,76.15 \pm 0.63$ and $76.61 \pm 0.75$, respectively. Thus DSELE showed remarkable dose dependant HRBC membrane stabilization activity which is found be comparable to standard drug dexamethasone.

\begin{tabular}{lllll}
\hline \multirow{2}{*}{$\begin{array}{l}\text { Ooncentration } \\
(\mu \mathrm{g} / \mathrm{ml})\end{array}$} & O.DValue & \multicolumn{3}{l}{ Percent inhibition } \\
\cline { 2 - 5 } 100 & DSELE & Dexamethasone & DSELE & Dexamethasone \\
200 & $0.075 \pm 0.013^{* *}$ & $0.091 \pm 0.013^{* *}$ & $65.44 \pm 6.05$ & $58.26 \pm 6.03$ \\
400 & $0.073 \pm 0.014^{* *}$ & $0.076 \pm 0.003^{* *}$ & $66.51 \pm 6.81$ & $65.14 \pm 1.49$ \\
800 & $0.068 \pm 0.011^{* *}$ & $0.068 \pm 0.005^{* *}$ & $68.65 \pm 5.11$ & $68.60 \pm 2.43$ \\
1000 & $0.063 \pm 0.011^{* *}$ & $0.052 \pm 0.002^{* *}$ & $70.8 \pm 5.32$ & $76.15 \pm 0.63$ \\
Control O.D :- $0.218 \pm 0.004$ & $0.051 \pm 0.00 I^{* *}$ & $73.09 \pm 5.63$ & $76.61 \pm 0.75$ \\
One way Anova : Df: 5,12 & & & \\
FValue & $0.058 \pm 0.012^{* *}$ & & & \\
\hline
\end{tabular}

Values are expressed in mean $\pm S . D(n=3)$ Student's t-test $(n=3)$, **P<0.0 I, compared to control.

\section{Inhibition of protein denaturation method}

The DSELE showed dose dependant inhibition of protein denaturation activity with consistent rise in per cent inhibition of protein denaturation (Figure 1). Inhibition of protein denaturation by DSELE at $100,200,400,800$ and $1000 \mu \mathrm{g} / \mathrm{ml}$ was found to be $47.62 \pm 2.25,55.15 \pm 2.04,56.41 \pm 0.51,77.66 \pm 2.88$ and $78.39 \pm 3.39$ per cent, respectively, while mean per cent inhibition of protein denaturation by dexamethasone at $100,200,400,800$ and $1000 \mu \mathrm{g} / \mathrm{ml}$ was found to be $40.29 \pm 2.88,46.89 \pm 2.07,69.96 \pm 1.36,84.25 \pm 3.40$ and $89.38 \pm 1.36$, respectively. The maximum per cent inhibition of protein denaturation by DSELE found to be lesser than dexamethasone.

\section{Cotton pellet granuloma in mice}

In cotton pellet granuloma test in mice, DSELE showed dose dependant significant $(\mathrm{P}<0.01)$ reduction in granuloma weights. Mean per cent inhibition of granuloma pellet in groups treated with DSELE at dose rates of 200 and $400 \mathrm{mg} / \mathrm{kg}$ was 18.66 and 19.5 , respectively, while per cent inhibition by dexamethasone was 26.5. Thus the DSELE showed significant $(\mathrm{P}<0.01)$ anti-inflammatory activity at 200 and $400 \mathrm{mg} / \mathrm{kg}$ concentration as compared to control group mice (Table 2). In phytochemical analysis D. sissoo extracts revealed the presence of anthroquinone, amino acids, protein, saponin, sterols, tannin, glycosides, flavonoids and phenols. 
The actual mechanism of action of DSELE showing HRBC membrane stabilization may be due to inhibition of release of lysosomal content of neutrophils at the site of inflammation. These lysosomal constituents are involved in bactericidal action by containing bactericidal enzyme and protease, when released extracellularly cause damage to tissue leads to inflammation. Some of the NSAIDs are known to possess membrane stabilization due to prevention of osmotic loss of intracellular electrolyte and fluid components. ${ }^{12}$ Compounds with membrane stabilizing properties are well known for their ability to interfere with release of phospholipases that trigger the formation of inflammatory mediators. ${ }^{13}$ The DSELE due to membrane stabilization effect may prevent efflux of these intracellular components which might interference with the release of phospholipases and alteration with the influx of calcium, as the influx of calcium is important in release of inflammatory mediators.

Denaturation of proteins is a well documented cause of inflammation and rheumatoid arthritis. Several anti-inflammatory drugs have shown dose dependent ability to inhibit thermally induced protein denaturation. Mechanism of denaturation probably involves alteration in electrostatic, hydrogen, hydrophobic and disulphide bonding. ${ }^{14}$ From the results it is speculated that DSELE may be capable of controlling the production of auto antigen and inhibits denaturation of protein in rheumatic disease.

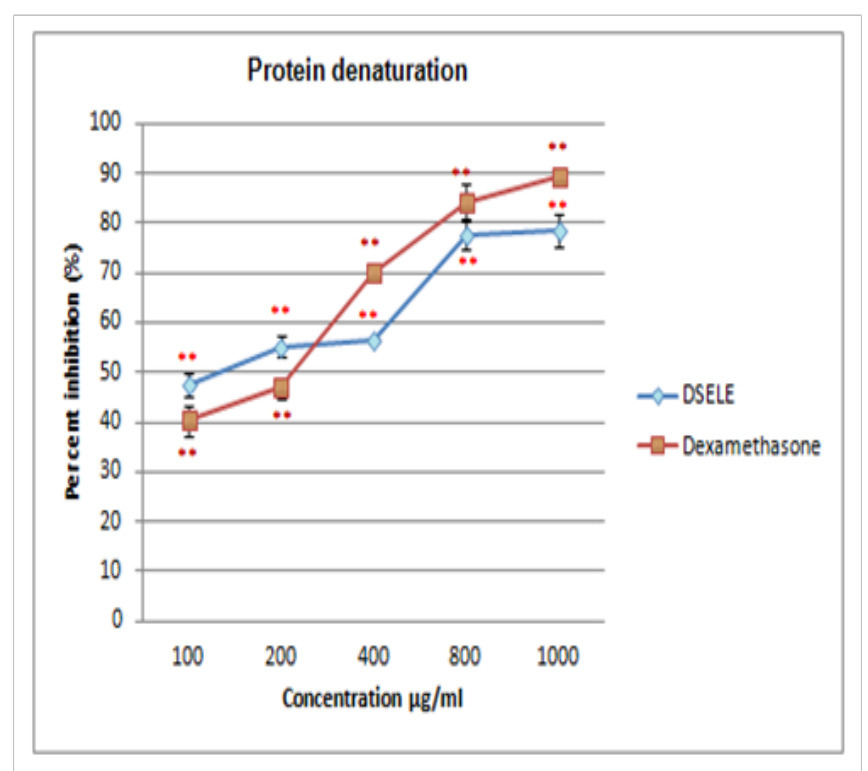

Figure I Effect of various concentrations of DSELE and dexamethasone on denaturation of protein.

Table 2 Effect of DSELE on wet and dry weight of cotton pellets in mice

\begin{tabular}{llllll}
\hline Treatment & Dose & $\begin{array}{l}\text { Mean wet } \\
\text { weight }\end{array}$ & $\begin{array}{l}\text { Percent } \\
\text { inhibition }\end{array}$ & $\begin{array}{l}\text { Mean dry } \\
\text { weight }\end{array}$ & $\begin{array}{l}\text { Percent } \\
\text { inhibition }\end{array}$ \\
\hline Control & N.S. & $104 \pm 7.96$ & & $37.16 \pm 2.98$ & \\
$\begin{array}{l}\text { Dexa mg/kg } \\
\text { DSELE mg/ }\end{array}$ & 1 & $65.16 \pm 2.34^{* *}$ & 63.16 & $9.66 \pm 0.77 * *$ & 27 \\
kg & 200 & $68.5 \pm 6.44^{* *}$ & 66 & $6.65 \pm 0.67 * *$ & 19 \\
& 400 & $71.66 \pm 7.55^{* *}$ & 69.33 & $6.96 \pm 1.14^{* *}$ & 20
\end{tabular}

One way Anova: $\mathrm{Df}=4,25$

F value $\quad 7.728 \quad 8.617$

Values are expressed in Mean $\pm S . E(n=6)$, Student's ' $t$ '-test, ${ }^{* * P}<0.01$, compared to control

Cotton pellet granuloma is a model of non immunological types of inflammation and edema is mainly due to proliferative phase of inflammation. ${ }^{15}$ Efficacy of DSELE in this in vivo test may be possibly due to inhibition of monocytes infiltration and fibroblast proliferation. Activated monocyte can release a series of pro-inflammatory cytokines and TNF- $\alpha .{ }^{16}$ From the study it is concluded that DSELE possess significant anti-inflammatory activity seen from its effect on HRBC membrane stabilization, inhibition of protein denaturation and from inhibition of granuloma formation in mice.

\section{Acknowledgements}

None.

\section{Conflict of interest}

The author declares no conflict of interest.

\section{References}

1. Champion HG, SK Seth. A revised survey of forest types of India. Manager of publications Delhi, Government of India press, India: Springer; 1968.
2. Lodhiyal Neelu, Lodhiyal LS, Pangtey YPS. Structure and function of Shisham forest in central Himalaya, India: dry matter dynamics. Ann Bot. 2002;89(1):41-54.

3. Kirtikar KR, Basu BD. Indian Medicinal Plants. Dehra Dun, India: International book distributors and publishers; 1993. p. 818-910.

4. Hajare SW, Chandra S, Sharma J, et al. Analgesic and antipyretic activities of Dalbergia sissoo leaves. Indian Journal of Pharmacology. 2000;32:357-360.

5. Hugar Mallinath H, Kallappa HM, Liyakath Ahmed MD. Phytochemical and pharmacological studies of ethanol extract of Dalbergia sissoo seeds: an approach for the in-vivo analgesic and antipyretic activities. International Journal of Pharma and Bio Sciences. 2010;1(4):0975-6299.

6. OECD. Guidance document on the recognition, assessment and use of clinical signs as humane end points for experimental animals used in safety evaluation environmental health and safety monograph series on testing and assessment No 19, France; 2000.

7. Sadique J, Al Rqobab NA, Bughaith MF, et al. The bioactivity of certain medicinal plants on the stabilization of RBC membrane system. Fitoterapia. 1989;60:525-532. 
8. Mizushima Y, Kobayashi M. Interaction of anti -inflammatory drugs with serum proteins, especially with some biologically active proteins. $J$ Pharm Pharmacol. 1968;20(3):169-173.

9. Aruoma OI. Free radicals, oxidative stress and antioxidants in human health and disease. Journal of American Oil Chemists Society. 1998;75(2):199-212.

10. Winter CA, Porter CC. Effect of alteration in side chain upon anti-inflammatory and liver glycogen activities of hydrocortisone esters. J Am Pharm Assoc Am Pharm Assoc. 1957;46(9):515-519.

11. Snedecor GW, Cochran WG. Statistical methods. 6th ed. New Delhi, India: Oxford and IBH; 1967. 593 p.

12. Khalid MM, Ansari AP, Rahman M, et al. Evaluation of ex-vivo cardioprotective and anti-inflammatory investigation of bangladeshi plants extract. Journal of Scientific Research \& Reports. 2015;7(1):58-66.
13. Aitadafouri M, Mounnnieri C, Heyman SF, et al. 4-Alkoxybenzamides as new potent phospholipase A2 inhibitors. Biochemical Pharmacology. 1996;51(5):737-742.

14. Arya D, Patni V. Comparative analysis of in vitro anti-inflammatory and anti-arthritic activity in methanolic extract of Pluchea lanceolata Oliver \& Hiern. Int J Biol Pharm Res. 2013;4(9):676-680.

15. Swnidle KF, Shiederman FE. Phases of inflammatory response to subcutaneous implantation of cotton pellet and their modification by certain anti-inflammatory agents. J Pharmacol Exp Ther. 1972;183(1):226-234.

16. Laupattarakasem $\mathrm{P}$, Wangsrimongkol $\mathrm{T}$, Surarit $\mathrm{R}$, et al. In vitro and In vivo anti-inflammatory potential of cryptoleisis buchanani. J Ethnopharmacol. 2006;108(3):349-354. 